\title{
Foraging by pine marten Martes martes in relation to food resources in Białowieża National Park, Poland
}

\author{
Włodzimierz JĘDRZEJEWSKI, Andrzej ZALEWSKI \\ and Bogumiła JĘDRZEJEWSKA
}

Jedrzejewski W., Zalewski A. and Jedrzejewska B. 1993. Foraging by pine marten Martes martes in relation to food resources in Białowieża National Park, Poland. Acta theriol. 38: $405-426$.

Feeding habits of pine marten Martes martes (Linnaeus, 1758) were studied in 1985 - 1992 in the pristine forests of Białowieża National Park, eastern Poland. The study covered 5 years of moderate numbers of forest rodents and 2 years of outbreak and crash. In 1735 analysed scats, rodents (Clethrionomys glareolus, Apodemus flavicollis, and Microtus sp.) were staple food for martens, constituting from $50 \%$ of biomass consumed in June to over 90\% in October - November. Birds (mainly thrushes and woodpeckers) were captured by martens mainly in spring and summer (up to $37 \%$ biomass in June). Vegetable matter (Rubus berries, Sorbus aucuparia fruit, mushrooms) was frequently eaten in July - October (up to $17 \%$ biomass in September) Ungulate carcasses were scavenged in winter. Marten preferred the remains of wolf and lynx kills and avoided ungulates that had died from undernutrition and/or disease. Between-year variation in marten diet was shaped by variation in rodent (especially bank vole) numbers. Percent of bank vole biomass in marten diet in autumn-winter was determined by the summer-autumn numbers of these rodents. Martens' consumption of mice in the cold season did not reflect the changes in mouse numbers, but it was positively correlated with their preying on bank voles. Spring numbers of mice determined the percentage of biomass of mice in marten diet in spring-summer. Snow cover significantly decreased martens' preying on $C$. glareolus, but not A. flavicollis and Microtus sp. In the cold season, insectivores and ungulate carcasses were crucial alternative food for the pine marten and they compensated for the decreased availability of rodents. In spring and summer, birds and fruit were alternative food, the consumption of which negatively correlated with the consumption of rodents. Snowtracking showed that in their search for prey, martens utilized both fallen and standing trees, and moved on the ground as well as in the forest canopy. Over 90\% of all recorded attacks were on rodents. Marten attacked rodents 4.1 times $/ \mathrm{km}$ of trail but $35 \%$ of attacks failed.

Mammal Research Institute, Polish Academy of Sciences, 17-230 Białowieża, Poland (WJ, AZ); Workshop for Ecology and Protection of the Natural Environment, P.O. Box 23, 17-230 Białowieża, Poland (BJ)

Key words: Martes martes, diet, seasonal variation, between-year variation, snowtracking, Białowieża National Park

\section{Introduction}

Pine marten Martes martes (Linnaeus, 1758) is one of the common, typically forest predators of Europe (Grakov 1981), which disappears wherever the forests 
are clearcut and turned into farmland (e.g. Langley 1977). Pine marten is a generalist predator in terms of its feeding habits; rodents, shrews, squirrels, birds, fruit and ungulate carcass constituted the bulk of its diet in Scandinavian boreal forests (Pulliainen 1980), Swiss Jura montane forests (Marchesi and Mermod 1989), woods of Scotland (Lockie 1961), mixed forests of central Poland (Goszczyński 1986), and temperate and boreal forests of the former Soviet Union (review in Grakov 1981). Due to both its terrestrial and arboreal hunting, the pine marten is an important predator of small rodents (Goszczyński 1977), birds (Sonerud 1985), and squirrels (Jurgenson 1954). As a medium-sized predator, marten is supposed to be affected by the depth of snow in its hunting for rodents (Hansson 1987).

This paper presents the results of 7-year research on the feeding habits of pine marten in Białowieża National Park (= BNP), eastern Poland. The study site provides a unique opportunity to investigate the nearly pristine situation of predators inhabiting the last remnant of primeval forest in lowland temperate Europe. The multi-annual pattern of rodent dynamics (bank vole Clethrionomys glareolus and yellow-necked mouse Apodemus flavicollis) in these forests consists of several consecutive years of non-cyclic dynamics (moderate densities) and outbreaks of rodents followed by deep crashes after synchronized mast production by oak, hornbeam and maple, which takes place at 6 to 9-year intervals (Pucek et al. 1993). Outbreak and crash last 2 years. Our study covered the entire series of 5 moderate years and 2 outbreak-crash years.

In BNP, the pine marten coexists with six other mustelid species (weasel Mustela nivalis, stoat $M$. erminea, polecat $M$. putorius, American mink $M$. vison, otter Lutra lutra, and badger Meles meles) as well as with red fox Vulpes vulpes, wolf Canis lupus, lynx Lynx lynx, and raccoon dog Nyctereutes procyonoides. In the winters of $1985 / 86$ to $1988 / 89$, the densities of pine marten in BNP varied from 5 to 8 inds $/ 10 \mathrm{~km}^{2}$. Marten was the third most numerous predator in the community, after tawny owl Strix aluco and weasel (Jędrzejewski and Jędrzejewska 1993). During moderate (non-cyclic) years of rodent dynamics, marten was an important predator of forest rodents in autumn and winter. By consuming an average of $3-5$ bank voles and 1.5 mice/ha, martens were estimated to contribute $13-14 \%$ to the total predation on voles and $10-11 \%$ to that on mice (Jędrzejewski and Jędrzejewska 1993).

In this paper, we analysed: (1) the seasonal and between-year variation of pine marten diet in relation to varying abundance of the main food resources (rodents, insectivores, ungulate carcasses, birds) and snow cover; (2) modes of marten foraging in winter.

\section{Study area}

Białowieża National Park (BNP), eastern Poland $\left(47.5 \mathrm{~km}^{2}, 23^{\circ} 55^{\prime} \mathrm{E}, 52^{\circ} 45^{\prime} \mathrm{N}\right.$ ) is a part of extensive woodlands dominated by oak Quercus robur, hornbeam Carpinus betulus, lime Tilia 
cordata, maple Acer platanoides, birches Betula verrucosa and B. pubescens, black alder Alnus glutinosa, spruce Picea abies, and pine Pinus sylvestris. BNP preserves the last remnants of primeval lowland forests of Europe, and is largely unaltered by management, hunting, and tourism (Faliński 1986). The fresh, fairly dry, swampy, and river-flooded forest associations with many decaying uprooted trees and regeneration taking place under the canopy of old growth, make the habitat diversified both in macro and micro scale. On its southern border, the Park adjoins the Białowieża Glade and its open meadows and fields, some of them abandoned and undergoing secondary forest succession. To the north, east and west the Park adjoins continuous forests. The western and northern borders of the Park are small rivers (Narewka and Hwoźna) with belts of treeless marshes up to 500 $\mathrm{m}$ wide. The furthest distance from the centre of BNP to the nearest open area (Białowieża Glade or river valleys) does not exceed $4 \mathrm{~km}$. The climate of Bialowieża is transitional between continental and Atlantic types (the continental features prevail), which makes the weather rather variable (Olszewski 1986).

\section{Material and methods}

\section{Food resources}

Rodents were trapped in the autumn, from 1986 to 1991, on 7 trapping sites in the forest and 7 sites located in open marshes, meadows, and fields. Each trapping site contained 10 devices (4 livetraps baited with oats and parsley, 4 snaptraps baited with oil and parsley, and 2 pitfalls with no bait) and was operated for 6 nights. The trapping was aimed at giving (1) the indices of rodent and shrew abundance in the forest and in the open areas in consecutive years and (2) the relative abundances of different species of small mammals.

Additionally, data for 1985 - 1991 from the long-term trapping of small mammals in BNP were used (Pucek et al. 1993). Small mammals were sampled by 50 cones, 50 livetraps and 50 snaptraps. The cones, distributed on a grid $5 \times 10 \mathrm{~m}$, covered $0.25 \mathrm{ha}(50 \times 50 \mathrm{~m})$. The line of snaptraps (baited with oil and placed at $10-\mathrm{m}$ intervals) was $100 \mathrm{~m}$ away from the grid of cones. The line of livetraps (baited with oats and placed at $10-\mathrm{m}$ intervals) was $50 \mathrm{~m} \mathrm{~W}$ of the snaptrap line and parallel to it. The removal trapping was conducted three times per year: in spring ( $43-47$ days from 15 April), summer ( $28-31$ days from 1 July), and autumn ( $30-47$ days from 15 September). We used the first 21 days of each trapping series to make the results of all series comparable. Two indices of rodent and shrew abundance were shown for each year: (1) the number of rodents or shrews caught in spring, and (2) the sum of rodents or shrews caught in summer and autumn. Analysis of the long-term trapping series $(1971-1991)$ have shown that the yearly peak of rodent and shrew abundance occurred either in summer or in autumn. Thus, we assumed that the summed index better reflected the year-to-year changes of their availability.

In the winters of $1986 / 87$ to $1991 / 92$, the western part of BNP (ca $15 \mathrm{~km}^{2}$ ) was searched for carcasses of ungulates either killed by wolves and lynx, or those that had died from other causes. At each carcass or kill, the utilization by predators and scavengers was noted and, whenever possible, the species of predator/scavenger was identified by tracks on snow.

Meteorological data were provided by the Białowieża meteorological station.

\section{Winter foraging modes of pine marten}

Data on foraging modes of pine martens in winter were obtained by snowtracking of individual martens. During the tracking an observer noted all activities of an animal that were readable from the tracks and signs on snow. The length of trail was measured by pacing or a special thread-device. The total material consisted of $64107 \mathrm{~m}$ of snowtracking. 


\section{Diet composition}

In total, 1735 scats collected from the winter of 1985/86 till the spring of 1992 were analysed. Most of the scats were taken from fallen logs, during the snowtracking of individual martens (in winter), and from rest sites. Analysis of scats followed the standard procedure (Lockie 1959, Goszczyński 1974). Prey was identified on the basis of bony remains and microscopic characteristics of hair according to the keys of Dziurdzik (1973), Debrot (1982), Pucek (1984) and März (1987). Food composition was expressed both in percent of biomass consumed and percent of occurrence in scats. The biomass of prey consumed was calculated by using the coefficients of digestibility: small mammals -23 , hares -50 , birds -35 , wild boar, domestic cattle and sheep carcasses (wild boar dead from undernutrition, full corpses of dead domestic animals) - 118 (all after Goszczyński 1974), red deer carcasses (remains of wolf kills) - 15 (after Jędrzejewski and Jędrzejewska 1992), amphibians and reptiles - 18 (after Fairley et al. 1987), plant material - 14, invertebrates - 5 (both after Lockie 1961), nonorganic matter - 1 (we assumed that it was not digestible).

\section{Results}

\section{Seasonal diet composition of pine marten}

Rodents (mainly bank vole Clethrionomys glareolus, yellow-necked mouse Apodemus flavicollis, and three species of voles Microtus sp.) were the most important marten food throughout year, constituting usually over $50 \%$ of biomass consumed by martens (Fig. 1). Seasonal pattern of rodent consumption was characterized by two distinct peaks and two lows during a year. The highest contribution of rodents to marten diet was observed in October and November (above 90\%), when rodent densities were seasonally high soon after ceasing reproduction (Fig. 2). Through winter (December, January, February) the share of rodents decreased to about $70 \%$ of biomass in March (Fig. 1). In spring (April and May) the amount of rodents in marten diet raised again to over $80 \%$ of the biomass eaten, despite the seasonally lowest numbers of rodents then (Figs 1 and 2). The share of rodents in marten diet was low in summer (only $50 \%$ in June), when numbers of rodents grew quickly (Fig. 2).

The seasonal pattern of martens' preying on the two most numerous forest rodents, the bank vole and the yellow-necked mouse, was similar except for the sharp increase of mouse share in marten diet in October - November (Fig. 2). Out of these two species of forest rodents, martens preyed on bank voles significantly more than could have been expected from their proportion in the total biomass of rodents of the two species trapped in the forest (Table 1).

Microtus voles were most numerous in marten diet in April - May (like forest rodents) and again in July - September (unlike forest rodents) (Fig. 2). Out of 323 scats including Microtus remains, the species of vole was determined in 128 cases; $44 \%$ were Microtus oeconomus, $30 \%$ were $M$. agrestis, and $26 \%$ were $M$. arvalis. All 3 species only sporadically occurred in the forests of BNP, but they inhabited the open river valleys and meadows in the park's buffer zone. Microtus remains were recovered from scats found in the entire forest. However, the ratio of Microtus dry weight to forest rodent dry weight in marten scats changed from 1:2 in the 


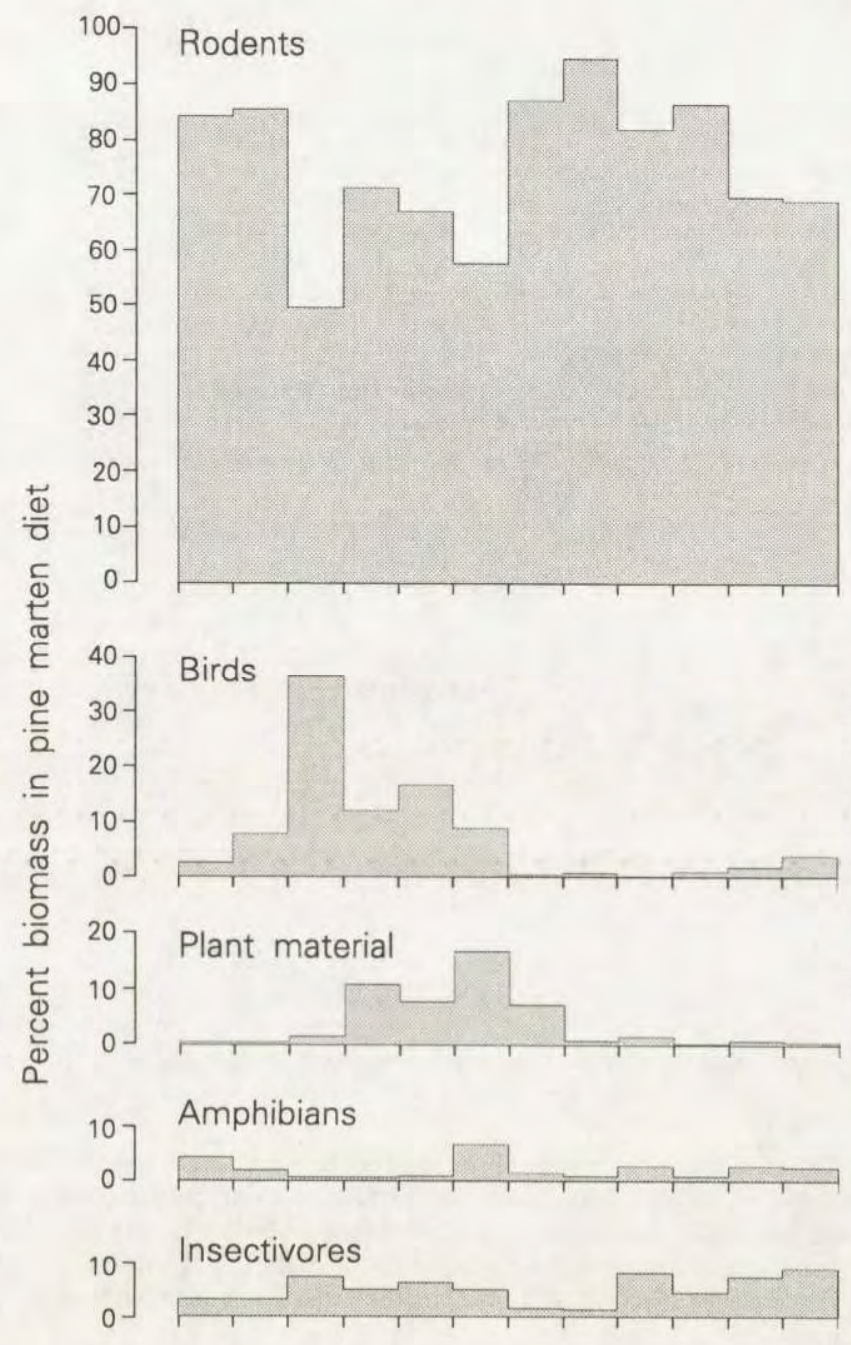

$\left.\begin{array}{l}20 \\ 10\end{array}\right]$

Fig. 1. Monthly changes in percent biomass of six main groups of food resources in pine marten diet in BNP (pooled data for 1985/86 - 1991/92). Food niche breadth (B) calculated after Levins (1968) for 10 main food groups (small rodents, insectivores, squirrel, hare, carnivores, ungulate carcass, birds, amphibians, insects, plant material): $\mathrm{B}=1 / \Sigma \mathrm{p}_{\mathrm{i}}{ }^{2}$, where $\mathrm{p}_{i}$ - percent biomass of a particular prey group.

\section{Ungulate carcasses}
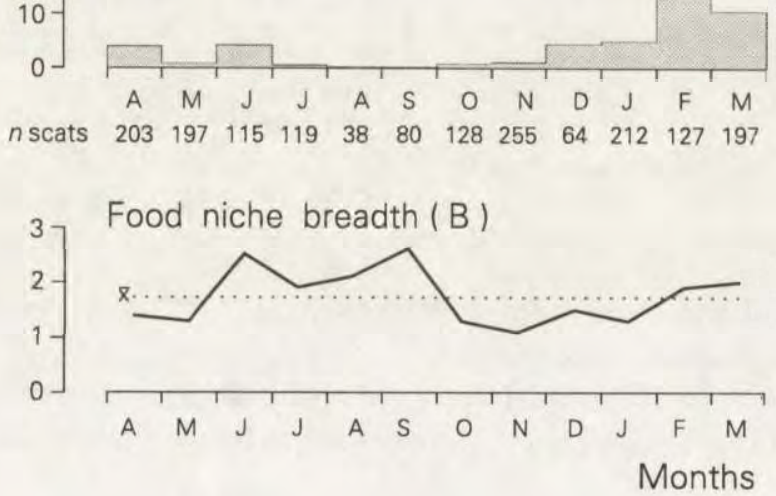


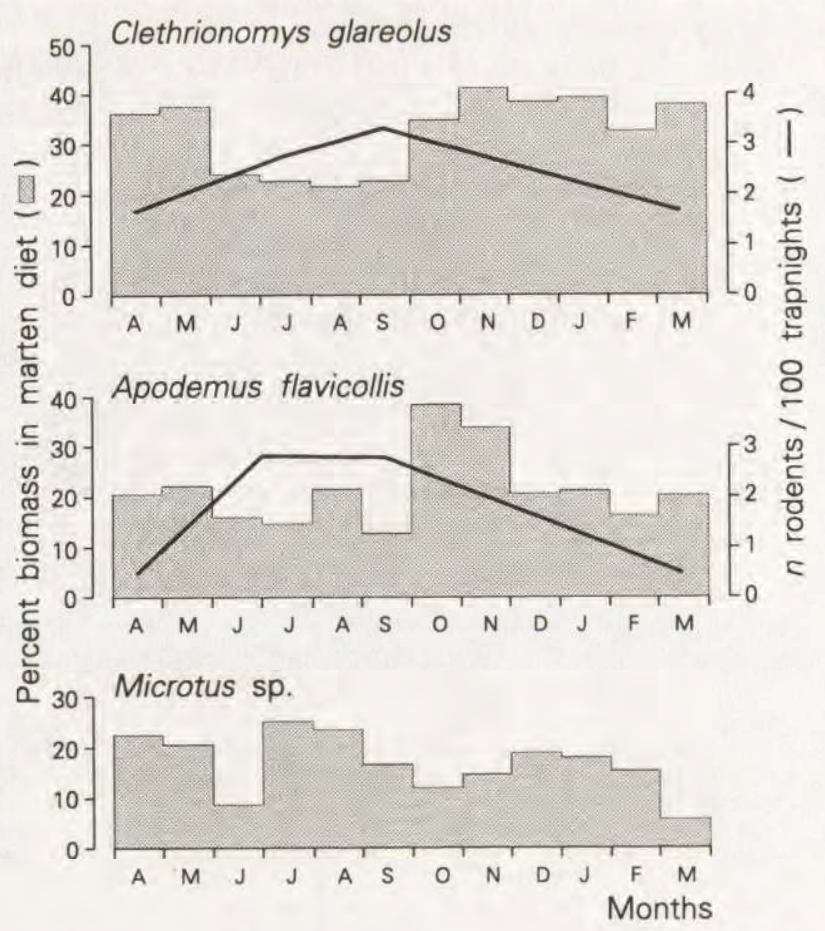

Fig. 2. Monthly changes in percent biomass of C. glareolus, A. flavicollis and Microtus sp. in marten diet (in 1985/86 - 1991/92). The seasonal changes in abundance of bank voles and yellow-necked mice were calculated from trapping conducted in April, July and September (averaged for 1985 - 1991).

Table 1. Selectivity of pine marten towards two species of rodents, Clethrionomys glareolus and Apodemus flavicollis. Data pooled from rodent trapping on 7 forest sites in $1986-1992 ; n$ - total number of captured rodents. Rodents in marten diet: data averaged for 7 autumn-winter and 6 spring-summer seasons (\% biomass as listed in Table 5). D - Ivlev's electivity index (Jacobs 1974). Proportions of voles and mice in the forest and in marten diet significantly different $(G=4.2, \mathrm{df}=1$, $p<0.05$ ).

\begin{tabular}{|c|c|c|c|c|c|c|c|}
\hline \multirow[b]{2}{*}{ Species } & \multirow{2}{*}{$\begin{array}{c}\text { Mean } \\
\text { body mass } \\
\text { (g) }\end{array}$} & \multicolumn{3}{|c|}{ Trapping in BNP } & \multicolumn{2}{|c|}{ Pine marten diet } & \multirow[b]{2}{*}{$\mathrm{D}$} \\
\hline & & $n$ & $\begin{array}{l}\text { Biomass } \\
\text { (g) }\end{array}$ & $\begin{array}{l}\text { Prop- } \\
\text { ortion }\end{array}$ & $\begin{array}{c}\text { Biomass } \\
(\%)\end{array}$ & $\begin{array}{l}\text { Prop- } \\
\text { ortion }\end{array}$ & \\
\hline Clethrionomys glareolus & 17 & 225 & 3825 & 0.47 & 32.6 & 0.61 & 0.28 \\
\hline Apodemus flavicollis & 31 & 140 & 4340 & 0.53 & 20.6 & 0.39 & -0.28 \\
\hline
\end{tabular}

1-km zone from the forest edge, to $1: 5$ in the forest interior $3-4 \mathrm{~km}$ from the nearest open area.

Among non-rodent prey of marten, birds were most important and preyed upon mainly in May - September, when migratory song-birds were abundant. In June, 
Table 2. Species and numbers $(n)$ of birds identified from marten scats in BNP. Spring-summer $=16$ April -30 September, autumn-winter $=1$ October -15 April.

\begin{tabular}{lccrr}
\hline & Spring-summer & Autumn-winter & \multicolumn{2}{c}{ Total } \\
\cline { 2 - 5 } Species/genus & $n$ & $n$ & $n$ & $\%$ \\
\hline Turdus philomelos & 6 & - & 6 & 19 \\
Turdus merula & 1 & 4 & 1 & 3 \\
Dendrocopos sp. & 1 & 2 & 4 & 12 \\
Sitta europaea & 2 & 1 & 4 & 12 \\
Ficedula sp. & 3 & - & 2 & 6 \\
Troglodytes troglodytes & 2 & - & 2 & 6 \\
Garrulus glandarius & 2 & - & 1 & 3 \\
Sturnus vulgaris & 1 & - & 1 & 3 \\
Parus caeruleus & 1 & - & 1 & 3 \\
Coccothraustes coccothraustes & 1 & 1 & 1 & 3 \\
Muscicapa striata & - & - & 1 & 3 \\
Erithacus rubecula & 1 & - & 1 & 3 \\
Columba sp. & 1 & 1 & 1 & 3 \\
Strix aluco & - & - & 16 & 50 \\
Buteo buteo & 1 & 8 & & 3 \\
Cavity nesters total & 8 & & & 1 \\
\hline
\end{tabular}

Table 3. Seasonal occurrence of fruit, mushrooms and seeds in pine marten diet in BNP (in number of scats containing given plant material). Data for $1985 / 86-1992$ pooled. Spring = 16 April -31 May, summer $=1$ June -30 September, autumn $=1$ October -31 December, winter $=1$ January -15 April.

\begin{tabular}{|c|c|c|c|c|c|c|c|}
\hline \multirow{2}{*}{ Item } & & \multirow{2}{*}{ Spring } & \multirow{2}{*}{ Summer } & \multirow{2}{*}{ Autumn } & \multirow{2}{*}{ Winter } & \multicolumn{2}{|c|}{ Total } \\
\hline & & & & & & $n$ & $\%$ \\
\hline Rubus sp. fruit & & 1 & 28 & 24 & 9 & 62 & 28 \\
\hline Mushrooms & & 6 & 8 & 22 & 15 & 51 & 23 \\
\hline Sorbus aucuparia fruit & & - & 26 & 19 & 1 & 46 & 20 \\
\hline Hornbeam seeds & • & - & 2 & 6 & 6 & 14 & 6 \\
\hline Oak seeds & & 1 & 1 & 4 & 6 & 12 & 5 \\
\hline Hazel nuts & & 1 & 2 & 5 & 3 & 11 & 5 \\
\hline Various and undetermined & & 11 & 3 & 9 & 6 & 29 & 13 \\
\hline
\end{tabular}

Table 4. Pine marten feeding at carcasses of ungulates in BNP. Number of carcasses found and observations of martens scavenging recorded at these carcasses include data pooled for the cold seasons of $1986 / 87$ to $1991 / 92$. D - ungulates dead from undernutrition and/or disease, K - remains of ungulates killed by wolves or lynx. Martens' choice of $\mathrm{K}$ versus $\mathrm{D}$ carcasses significantly different $(G=38.2, \mathrm{df}=1, p<0.001)$.

\begin{tabular}{|c|c|c|c|c|c|c|}
\hline \multirow{2}{*}{ Parameter } & \multicolumn{2}{|c|}{ Deer } & \multicolumn{2}{|c|}{ Wild boar } & \multirow{2}{*}{ Total } & \multirow{2}{*}{$\begin{array}{l}\text { Deer : boar } \\
\text { ratio }\end{array}$} \\
\hline & $\mathrm{D}$ & $\mathrm{K}$ & $\mathrm{D}$ & $\mathrm{K}$ & & \\
\hline Found in BNP & 25 & 86 & 118 & 16 & 245 & $1: 1.2$ \\
\hline Martens scavenged at & 2 & 15 & 5 & 3 & 25 & $1: 0.5$ \\
\hline Percent utilized by martens (\%) & 8 & 17 & 4 & 19 & 10 & \\
\hline
\end{tabular}


Table 5. Diet composition (\% occurrence in scats and \% biomass consumed) of marten in BNP in 10 main groups of food (see Fig. 1). AW - autumn-winter (1 October - 15 April), SS - spring-summer

\begin{tabular}{|c|c|c|c|c|c|c|c|c|c|c|c|c|}
\hline \multirow[t]{2}{*}{ Item } & \multicolumn{2}{|c|}{$\begin{array}{c}1985 / 86(\mathrm{AW}) \\
n=21\end{array}$} & \multicolumn{2}{|c|}{$\begin{array}{c}1986 \text { (SS) } \\
n=110\end{array}$} & \multicolumn{2}{|c|}{$\begin{array}{c}1986 / 87(\mathrm{AW}) \\
n=282\end{array}$} & \multicolumn{2}{|c|}{$\begin{array}{c}1987 \text { (SS) } \\
n=181\end{array}$} & \multicolumn{2}{|c|}{$\begin{array}{c}1987 / 88(\mathrm{AW}) \\
n=232\end{array}$} & \multicolumn{2}{|c|}{$\begin{array}{c}1988(\mathrm{SS}) \\
n=59\end{array}$} \\
\hline & $\% \mathrm{Occ}$ & $\%$ Bio & $\% \mathrm{Occ}$ & $\%$ Bio & $\% \mathrm{Occ}$ & $\%$ Bio & $\% \mathrm{Occ}$ & $\%$ Bio & $\%$ Occ & $\%$ Bio & $\% \mathrm{Occ}$ & $\%$ Bio \\
\hline $\begin{array}{l}\text { Clethrionomys } \\
\text { glareolus }\end{array}$ & 28.6 & 11.1 & 36.4 & 26.5 & 46.1 & 38.9 & 43.1 & 38.3 & 46.6 & 39.5 & 50.9 & 41.7 \\
\hline Apodemus flavicollis & 14.3 & 10.2 & 32.7 & 29.5 & 36.5 & 31.1 & 21.0 & 19.6 & 30.6 & 21.2 & 15.3 & 10.4 \\
\hline Microtus sp. & 23.8 & 24.9 & 37.7 & 25.1 & 23.4 & 17.6 & 25.4 & 20.9 & 23.7 & 19.0 & 27.1 & 22.6 \\
\hline Other rodents & 4.8 & 4.3 & 9.1 & 3.9 & 4.3 & 3.9 & 15.5 & 9.4 & 5.2 & 5.9 & 8.5 & 4.2 \\
\hline Small rodents total & 66.7 & 50.5 & 90.0 & 85.0 & 87.6 & 91.5 & 90.6 & 88.2 & 91.8 & 85.6 & 89.8 & 78.9 \\
\hline Sciurus vulgaris & 19.1 & 20.5 & - & - & - & - & 0.6 & 0.3 & 0.9 & 0.9 & 1.7 & 0.2 \\
\hline Lepus europaeus & 4.8 & 5.2 & - & - & 1.4 & 1.2 & - & - & - & - & - & - \\
\hline Soricidae & 4.8 & 0.5 & 7.3 & 5.8 & 5.3 & 1.7 & 5.5 & 2.2 & 9.5 & 3.3 & 1.7 & 0.8 \\
\hline Talpa europaea & 4.8 & 6.2 & - & - & 0.4 & 0.1 & 1.7 & 0.6 & 6.5 & 3.2 & 5.0 & 3.0 \\
\hline Erinaceus europaeus & 4.8 & 10.3 & - & - & - & - & - & - & - & - & - & - \\
\hline Insectivora total & 9.5 & 17.0 & 7.3 & 5.8 & 5.7 & 1.8 & 7.2 & 2.8 & 15.5 & 6.5 & 6.8 & 3.8 \\
\hline Chiroptera & - & - & - & - & - & - & - & - & - & - & - & - \\
\hline Mustelidae & - & - & - & - & - & - & - & - & 0.4 & 0.1 & 1.7 & 2.0 \\
\hline Felis c & - & - & - & - & - & - & - & - & - & - & - & - \\
\hline Sus scrofa carcass & 4.8 & 0.5 & 0.9 & 0.4 & - & - & 0.6 & 0.2 & 1.7 & 2.6 & 3.4 & 1.2 \\
\hline Cervidae carcass & 9.5 & 0.4 & 0.9 & + & 5.0 & 0.6 & 1.7 & + & 6.9 & 1.1 & - & - \\
\hline Cattle carcass & - & - & - & - & 0.4 & 0.4 & - & - & - & - & - & - \\
\hline Carcasses total & 9.5 & 0.9 & 1.8 & 0.4 & 5.3 & 1.0 & 2.2 & 0.2 & 8.6 & 3.7 & 3.4 & 1.2 \\
\hline Birds & 4.8 & 0.9 & 16.4 & 5.1 & 1.4 & 0.4 & 15.5 & 6.3 & 6.0 & 1.7 & 8.5 & 3.6 \\
\hline $\begin{array}{l}\text { Amphibians and } \\
\text { reptiles }\end{array}$ & 14.3 & 3.7 & 8.2 & 0.5 & 11.0 & 0.7 & 9.9 & 0.7 & 11.2 & 1.0 & 11.9 & 1.4 \\
\hline Invertebrates & 23.8 & 0.4 & 25.5 & 0.3 & 11.7 & 0.9 & 10.5 & 0.6 & 13.8 & 0.2 & 23.7 & 0.8 \\
\hline Fruit & 14.3 & 0.9 & 9.1 & 1.4 & 13.8 & 1.8 & 6.1 & 0.6 & 10.3 & 0.3 & 16.9 & 7.2 \\
\hline Other plant matter & - & - & 12.7 & 1.5 & 10.3 & 0.7 & 6.1 & 0.3 & 0.4 & + & 11.9 & 0.9 \\
\hline Nonorganic material & - & - & 0.9 & + & 1.1 & + & - & - & 0.4 & + & - & - \\
\hline Niche breadth B & & 2.7 & & & & 1.2 & & 1.3 & & 1.3 & & 1.6 \\
\hline $\begin{array}{l}\text { Mean biomass con- } \\
\text { sumed per } 1 \text { scat (g) }\end{array}$ & & 21.7 & & 19.1 & & 18.7 & & 14.7 & & 16.6 & & 13.8 \\
\hline
\end{tabular}

birds made $37 \%$ of biomass consumed by martens (Fig. 1). Out of 200 scats containing bird remains, only in 32 cases the species or genus of bird was determined. Song thrushes dominated the sample in spring-summer, whereas woodpeckers in autumn-winter season (Table 2). Additionally, 7 scats collected in spring-summer seasons contained egg-shells.

Vegetal matter was frequently taken in July - October, with a maximum average share of $17 \%$ in the biomass consumed in September (Fig. 1). Martens most often ate Rubus berries (mainly $R$. idaeus), mushrooms, and rowan fruit (Table 3). 
1985/86 - 1991/92. $n$ - number of scats analysed, B - niche breadth (after Levins 1968) calculated for (16 April - 30 September). + - traces.

\begin{tabular}{|c|c|c|c|c|c|c|c|c|c|c|c|c|c|}
\hline \multicolumn{2}{|c|}{$\begin{array}{c}1988 / 89(\mathrm{AW}) \\
n=128\end{array}$} & \multicolumn{2}{|c|}{$\begin{array}{c}1989 \text { (SS) } \\
n=78\end{array}$} & \multicolumn{2}{|c|}{$\begin{array}{c}1989 / 90(\mathrm{AW}) \\
n=89\end{array}$} & \multicolumn{2}{|c|}{$\begin{array}{c}1990(\mathrm{SS}) \\
n=51\end{array}$} & \multicolumn{2}{|c|}{$\begin{array}{c}1990 / 91 \text { (AW) } \\
n=230\end{array}$} & \multicolumn{2}{|c|}{$\begin{array}{c}1991(\mathrm{SS}) \\
n=125\end{array}$} & \multicolumn{2}{|c|}{$\begin{array}{c}1991 / 92(\mathrm{AW}) \\
n=149\end{array}$} \\
\hline$\% \mathrm{Occ}$ & $\%$ Bio & $\% \mathrm{Occ}$ & $\%$ Bio & $\% \mathrm{Occ}$ & $\%$ Bio & $\%$ Occ & $\%$ Bio & $\%$ Occ & $\%$ Bio & $\%$ Occ & $\%$ Bio & $\%$ Occ & $\%$ Bio \\
\hline 50.0 & 38.4 & 41.0 & 35.2 & 49.4 & 40.6 & 45.1 & 43.4 & 53.5 & 45.3 & 14.4 & 14.6 & 13.4 & 10.1 \\
\hline 31.3 & 22.5 & 19.2 & 18.5 & 41.6 & 26.9 & 35.3 & 25.8 & 31.3 & 25.3 & 13.6 & 8.1 & 26.2 & 19.3 \\
\hline 8.6 & 5.6 & 14.1 & 9.2 & 28.1 & 22.1 & 27.5 & 19.3 & 13.0 & 11.8 & 10.4 & 9.8 & 5.4 & 3.0 \\
\hline 6.3 & 4.7 & - & - & 9.0 & 3.0 & - & - & 14.8 & 11.9 & 4.8 & 3.3 & 3.4 & 1.8 \\
\hline 86.7 & 71.2 & 67.9 & 62.9 & 98.9 & 92.6 & 94.1 & 88.5 & 93.0 & 94.2 & 38.4 & 35.8 & 43.6 & 34.2 \\
\hline- & - & - & - & - & - & - & - & 0.4 & 0.4 & - & - & - & - \\
\hline- & - & $\overline{-}$ & - & - & - & - & - & - & - & - & - & - & - \\
\hline 8.6 & 6.5 & 5.1 & 1.9 & 2.3 & 1.1 & 2.0 & 0.7 & 3.9 & 0.8 & 8.0 & 2.5 & 6.0 & 2.7 \\
\hline 4.7 & 3.9 & 7.7 & 5.2 & - & - & - & - & 2.6 & 1.4 & 2.4 & 2.8 & 8.7 & 6.1 \\
\hline- & - & - & - & - & - & - & - & - & - & - & - & - & - \\
\hline 13.3 & 10.5 & 12.2 & 7.1 & 2.3 & 1.1 & 2.0 & 0.7 & 6.1 & 2.2 & 11.2 & 5.3 & 14.8 & 8.8 \\
\hline- & - & - & - & - & - & - & - & - & - & 0.8 & + & - & - \\
\hline - & - & 1.3 & 2.4 & - & - & 2.0 & 2.4 & - & - & 0.8 & 0.1 & - & - \\
\hline- & - & - & - & - & - & - & - & 0.4 & + & - & - & 2.7 & 8.0 \\
\hline 1.6 & 7.1 & 2.6 & 0.5 & 3.4 & 4.5 & - & - & 2.2 & 1.3 & 1.6 & 0.4 & 8.0 & 12.6 \\
\hline 5.5 & 0.4 & 6.4 & 0.6 & 2.3 & + & 2.0 & + & 3.0 & 0.3 & 15.2 & 4.4 & 32.2 & 11.7 \\
\hline- & - & - & - & - & - & - & - & - & - & - & - & - & - \\
\hline 7.0 & 7.5 & 7.7 & 1.1 & 5.6 & 4.5 & 2.0 & + & 5.2 & 1.6 & 16.8 & 4.8 & 38.9 & 24.3 \\
\hline 7.8 & 5.1 & 32.0 & 20.9 & 1.1 & 0.2 & 15.7 & 7.2 & 2.6 & 0.6 & 45.6 & 37.6 & 10.7 & 6.8 \\
\hline 24.2 & 3.1 & 11.5 & 2.3 & 5.6 & 0.7 & 3.9 & 0.4 & 7.8 & 0.6 & 16.0 & 4.6 & 40.9 & 13.4 \\
\hline 22.7 & 1.0 & 28.2 & 1.7 & 7.9 & 0.2 & 9.8 & 0.1 & 9.1 & 0.1 & 47.2 & 1.1 & 35.6 & 1.5 \\
\hline 10.2 & 0.5 & 9.0 & 0.3 & 7.9 & 0.7 & 11.8 & 0.6 & 6.5 & 0.2 & 28.8 & 10.0 & 10.7 & 2.8 \\
\hline 9.4 & 0.4 & 19.3 & 1.3 & 3.4 & + & 5.9 & 0.1 & 1.8 & + & 8.8 & 0.7 & 2.7 & 0.2 \\
\hline- & - & - & - & - & - & - & - & - & - & - & - & - & - \\
\hline & 1.9 & & 2.2 & & 1.1 & & 1.3 & & 1.1 & & 3.5 & & 4.0 \\
\hline & 13.2 & & 11.3 & & 18.7 & & 14.2 & & 17.4 & & 12.9 & & 9.9 \\
\hline
\end{tabular}

Amphibians (mainly Rana temporaria) were preyed in small quantities throughout the year (Fig. 1), but their share in marten diet grew somewhat in April (4\%) during spawning season and in September $(6.5 \%)$ during their seasonal migrations to hibernation sites.

Among small insectivores identified from marten scats $(n=125)$, Sorex araneus formed $50 \%$, Talpa europaea - 33\%, Sorex minutus - 10\%, and Neomys fodiens $7 \%$. The consumption of insectivores was most intense in midsummer and midwinter (Fig. 1). 
Table 6. Seasonal occurrence of invertebrates in pine marten diet (in number of scats containing a given item) in BNP. Data for 1985/86 - 1992 pooled. Seasons as in Table 3.

\begin{tabular}{|c|c|c|c|c|c|c|}
\hline \multirow{2}{*}{ Item } & \multirow{2}{*}{ Spring } & \multirow{2}{*}{ Summer } & \multirow{2}{*}{ Autumn } & \multirow{2}{*}{ Winter } & \multicolumn{2}{|c|}{ Total } \\
\hline & & & & & $n$ & $\%$ \\
\hline Vespidae and Apidae & 22 & 62 & 35 & 47 & 166 & 45 \\
\hline Carabidae beetles & 10 & 14 & 31 & 12 & 67 & 18 \\
\hline Snails & 6 & 5 & 11 & 13 & 35 & 9 \\
\hline Insect larvae & 3 & 1 & 9 & 19 & 32 & 9 \\
\hline Undet. Coleoptera & 10 & 6 & 9 & 6 & 31 & 8 \\
\hline Earthworms & 3 & 3 & 1 & 5 & 12 & 3 \\
\hline Undet. insects & 9 & 2 & - & 15 & 26 & 7 \\
\hline
\end{tabular}

Ungulate carcasses were strictly a cold season food resource, with a maximum consumption in February (Fig. 1). Out of 245 ungulate carcasses found throughout the study, $25(10 \%)$ bore the signs of martens' scavenging (Table 4$)$. This figure made the pine marten the second most important scavenger, after the red fox Vulpes vulpes, the tracks of which were found at $20 \%$ of all carcasses. Martens preferred to feed on the remains of wolf and lynx kills (either deer or wild boar) rather than on ungulates that had died from disease and/or undernutrition (Table 4). Since deer (both roe and red deer) suffered more from wolf and lynx predation than did the wild boar (Jędrzejewski et al. 1992b), martens scavenged more on cervid carcasses than on those of wild boar (Table 4). Similar data were obtained from scat analysis; the mean percent of occurrence of cervid remains in scats in 7 autumn-winter seasons was 9.2, whereas that of wild boar remains 3.1 (Table 5).

Invertebrates formed little biomass in marten diet (up to $3 \%$ of biomass in September), but occurred in up to $51 \%$ of scats, indicating frequent foraging of martens on invertebrates. Hymenoptera insects (wasps, honey bees, bumble bees) and Carabidae beetles dominated the invertebrate prey of martens (Table 6). Out of 166 scats containing Hymenoptera insects, 99 cases were identified to species or genus: Vespula vulgaris L. - 33, Vespa crabro L. - 20, Bombus sp. - 17, Apis mellifera L. - 12, Vespula rufa L. - 7, Delichovespula media Deg. - 4, Vespula germanica Fabr. -3, D. saxonica Fabr. - 2, and Coelioxys sp. - 1. This list includes both crown-nesting and ground-nesting species.

The food niche of pine marten was relatively narrow and its breadth oscillated from 1.1 in November (when rodents heavily dominated marten diet) to 2.5 in June and 2.6 in September, when seasonal resources (birds and fruit) were at their highest abundance (Fig. 1).

\section{Between-year variation in diet composition}

The abundance of forest rodents (bank vole and yellow-necked mouse), the main resource for marten, varied between years. In 1985 - 1989 their numbers were 
Fig. 3. Between-year variation in percent biomass of $C$. glareolus, A. flavicollis and Microtus sp. in the autumn-winter (1 October - 15 April) diet of marten in relation to abundance of these rodents. In C. glareolus and $A$. flavicollis, the summer-autumn indices of numbers were used. In Microtus voles, autumn indices of numbers were used; upper dashed line: vole abundance in the open areas of BNP buffer zone, lower dashed line: vole abundance in BNP forests. (No data on Microtus in 1985 were available).
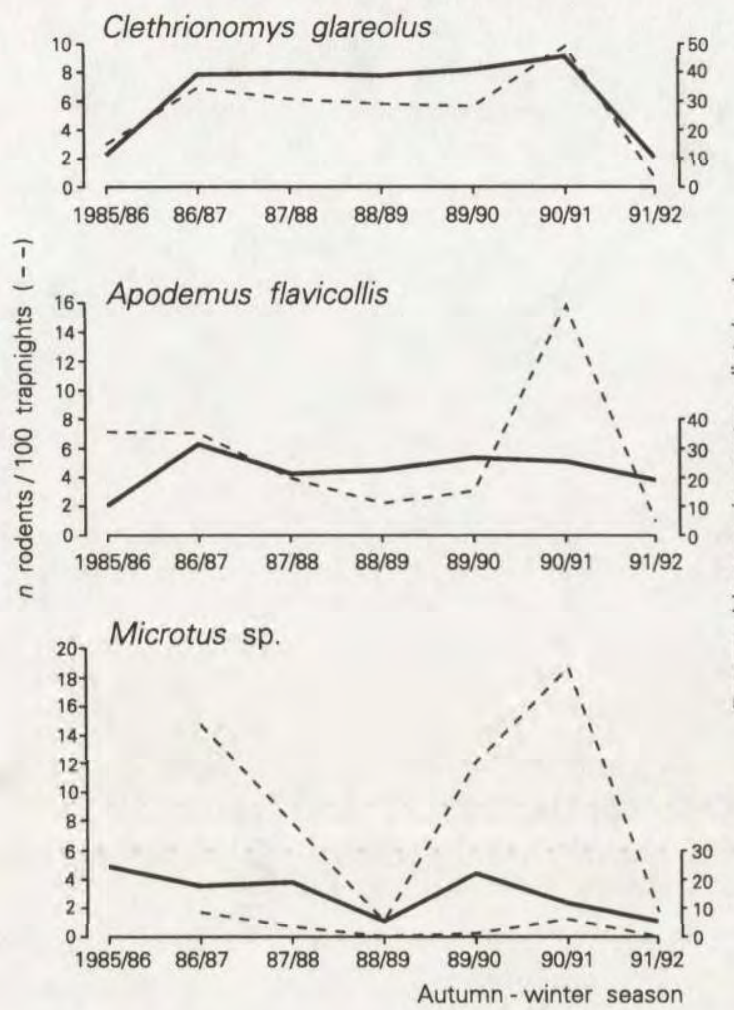

$$
\text { tus in } 1985 \text { were available). }
$$

Fig. 4. Between-year variation in percent biomass of C. glareolus and A. flavicollis in the spring-summer (16 April - 30 September) diet of marten in relation to the spring indices of numbers of these rodents in BNP.

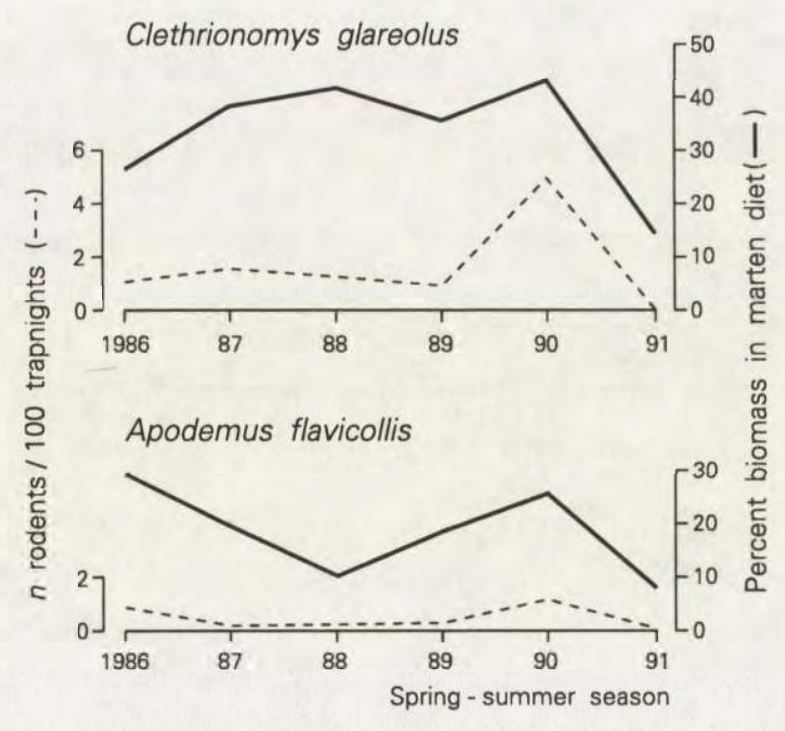




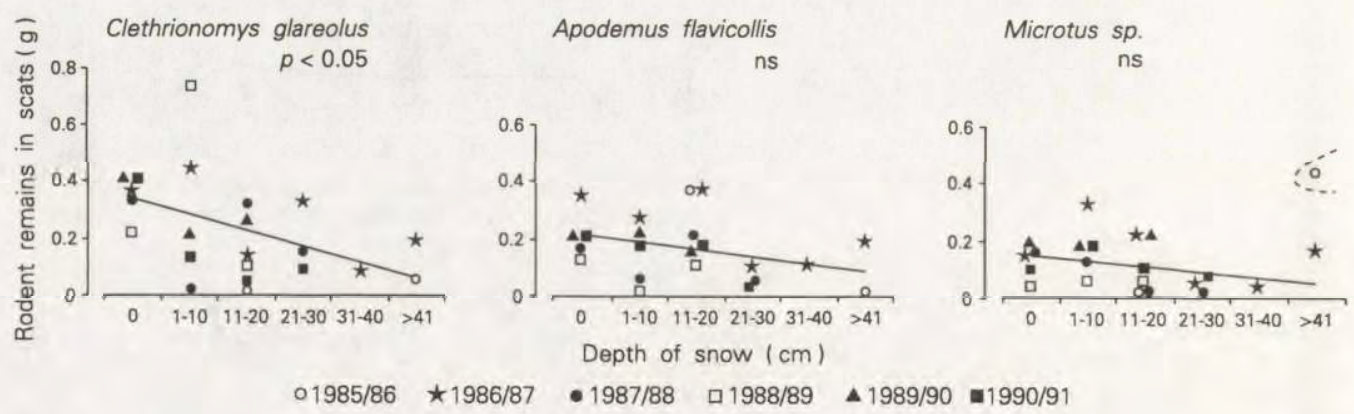

Fig. 5. Relationship between snow cover and the dry weight of rodent remains in marten scats. Each point represents a mean for scats (minimum sample size was 5) collected at a given snow depth in a given year. Regression lines calculated for those means. C. glareolus: $y=0.31-0.006 x, R^{2}=20 \%$, df $=20, p=0.038$. A. flavicollis: $y=0.205-0.0026 x, R^{2}=12 \%$, ns. Microtus sp. (a marked point excluded because of a possible bias due to peak numbers of voles in 1985/86): $y=0.136-0.002 x, R^{2}=8 \%$, ns.

moderate. In 1989, a heavy seed crop of oak, hornbeam and maple occurred and caused an outbreak of forest rodents in 1990. In 1991, both species crashed to very low numbers (Fig. 3). Microtus voles showed pronounced between-year variations: two peaks (in 1986 and 1990) and two lows (in 1988 and 1991) were recorded (Fig. 3). Varying food abundance affected the diet composition of martens both in spring-summer and in autumn-winter seasons (Table 5).

Percent biomass of bank voles in pine marten diet in autumn-winter correlated with summer-autumn numbers of these rodents (Fig. 3): $y=7.5+4.5 x, \mathrm{df}=5$, $R^{2}=82 \%, p=0.005$. In spring and summer this relationship was marked, although statistically not significant (Fig. 4 ): $R^{2}=45 \%, p=0.147$. The share of Apodemus in biomass taken by martens in cold seasons was not related to the abundance of mice in summer-autumn (Fig. 3 ): $R^{2}=2 \%, p=0.76$. However, the biomass of bank voles and that of mice in marten diet in autumn and winter were mutually correlated $(y=11.3+0.35 x, \mathrm{df}=5, r=0.77, p=0.044)$. In spring and summer, the biomass of mice in marten diet was related to the spring abundance of mice (Fig. 4): $y=11.6+15.3 x, \mathrm{df}=4, R^{2}=67 \%, p=0.047$. Cyclic changes in Microtus abundance were only weakly reflected in percent biomass of Microtus in marten

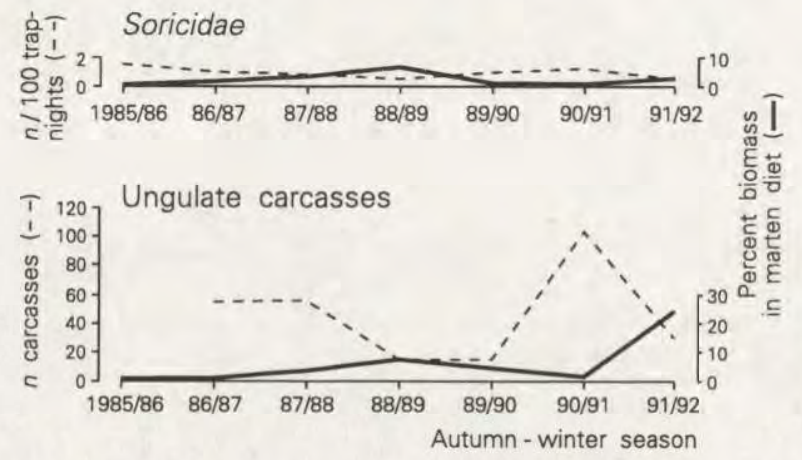

Fig, 6. Between-year variation in percent biomass of Soricidae and ungulate carcasses in marten diet in autumn-winter (1 October - 15 April) in relation to the abundance of shrews (summer-autumn indices of numbers) and ungulate carcasses. No data on carcass numbers in 1985/86. 
Spring-summer

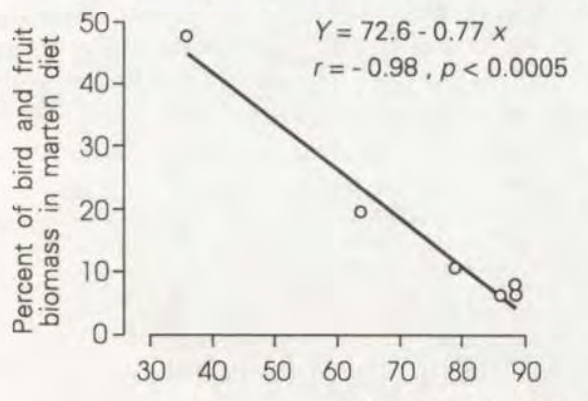

Percent of rodent biomass in marten diet
Autum! - winter

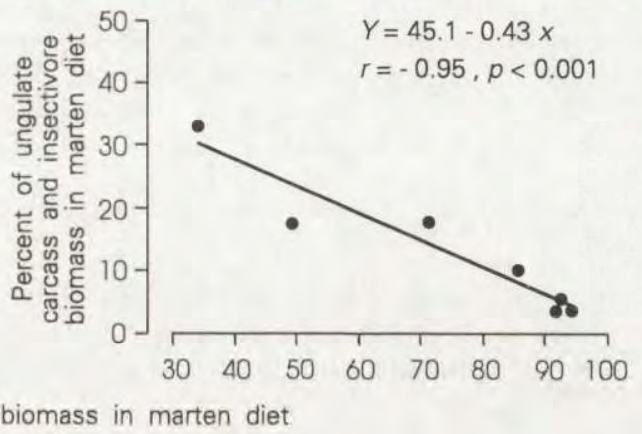

Fig. 7. Correlations between the percent biomass of rodents and percent biomass of alternative food resources in marten diet in BNP. Each point represents one season; spring-summer $=16 \mathrm{April}-30$ September, autumn-winter $=1$ October -15 April.

diet in autumn and winter (Fig. 3 ): $R^{2}=20 \%, \mathrm{df}=4, p=0.37$ (indices of vole abundance in BNP forests) or $R^{2}=38 \%, \mathrm{df}=4, p=0.19$ (indices of vole abundance in open areas).

Snow cover depth was an important factor decreasing marten consumption of bank voles (Fig. 5). On average, the weight of bank vole remains in marten scats decreased from $0.31 \mathrm{~g} / \mathrm{scat}$ at no snow cover to $0.04 \mathrm{~g} / \mathrm{scat}$ at snow $>41 \mathrm{~cm}$ deep, that is by $87 \%$. The decrease of marten's consumption of mice and Microtus voles was slight and statistically not significant (Fig. 5).

Marten consumption of shrews and ungulate carcasses in autumn-winter seasons was shaped by the abundance of rodents rather than by the abundance of these two resources (Fig. 6). Ungulate carcasses and insectivores were crucial alternative food to martens in autumn-winter, and they compensated for the decreased availability and numbers of rodents (Fig. 7). In spring and summer, birds and fruit were the most important alternative food, the consumption of which negatively correlated with martens' consumption of rodents (Fig. 7).

\section{Winter foraging and area searching by marten}

Snowtracking of individual martens during the winters of 1985/86 to 1991/92 showed that in their searching for prey in the pristine, mature forests, these predators utilized fallen logs, root plates of fallen trees, standing trees, and it moved on the ground as well as in forest canopy (Table 7). Most of attacks (92.3\%) were on rodents. In 49 attacks (i.e. 19\% of all observed attacks on rodents), the hunting success was unambiguously determined; 32 of them were successful (65\%) and $17(35 \%)$ ended with failure. In 152 attacks on rodents, the detail description of place was given. They included attacks near and under the fallen logs and branches and root plates of fallen trees (37\%), at roots of growing trees $(27 \%)$, and in places far from trees $(36 \%)$. 
Table 7. Modes of marten foraging in snow period as revealed by snowtracking of individual martens in 1985/86-1991/92 in BNP. The total length of snowtracking was $64107 \mathrm{~m}$. ${ }^{1}$ in parentheses: mean distance of a given area searching mode (in meters per $1 \mathrm{~km}$ of trail); ${ }^{2}$ the mean straight line distance of air-walk was $4.2 \mathrm{~m} ;{ }^{3}$ includes 0.03 shrews $/ \mathrm{km}$ killed and left uneaten; ${ }^{4}$ one red deer killed by wolves, one roe deer killed by lynx, one dead red deer; ${ }^{5}$ one bank vole and one shrew.

\begin{tabular}{|c|c|}
\hline Parameter & $n / 1 \mathrm{~km}$ of trail \\
\hline \multicolumn{2}{|l|}{ Modes of area searching } \\
\hline Walking: along fallen log and root plate of fallen tree & $6.5(21)^{1}$ \\
\hline under the fallen log or branches & $15.7(25)^{1}$ \\
\hline on log and root plate of fallen tree & $21.9(40)^{1}$ \\
\hline round the base of standing tree & 6.1 \\
\hline Penetrating the cavity or hollow tree & 0.8 \\
\hline Climbing the growing tree ${ }^{2}$ & 1.0 \\
\hline Number of loops on own trail & 2.7 \\
\hline \multicolumn{2}{|l|}{ Attacks and foraging } \\
\hline Attacks on rodents (total) & $4.1(92.3 \%)$ \\
\hline by scratching snow & 3.6 \\
\hline by jumping or chasing prey & 0.3 \\
\hline by digging into rodent burrow & 0.2 \\
\hline Attacks on: squirrel & $0.05(1.1 \%)$ \\
\hline bird & $0.03(0.7 \%)$ \\
\hline weasel & $0.02(0.5 \%)$ \\
\hline shrew $^{3}$ & $0.05(1.1 \%)$ \\
\hline Digging in mud for frogs & $0.05(1.1 \%)$ \\
\hline Scavenging on ungulate carcasses ${ }^{4}$ & $0.06(1.4 \%)$ \\
\hline Feeding on previously cached food ${ }^{5}$ & $0.05(1.1 \%)$ \\
\hline Foraging on plant material and mushrooms & $0.02(0.5 \%)$ \\
\hline Total number of attacks and foraging & $4.44(100 \%)$ \\
\hline
\end{tabular}

Although pine martens hunted for or fed on 8 types of prey, their niche breadth (calculated for attacked prey, Table 7) was very narrow (1.2), because attacks on rodents dominated heavily. This niche breadth value is the same as that calculated from scat content in winter (see Fig. 1).

\section{Discussion}

Our data collected in the pristine, mature forests of the nemoral zone in Europe showed that pine marten is excellently adapted to the exploitation of forest resources. By a systematic search, it penetrates the forest floor, logs and root plates of fallen trees, and canopies of growing trees. The modes of martens' searching for prey followed the routes of bank vole movements and hiding places, i.e. under and along the fallen logs and boughs (Olszewski 1968). The same mode of area searching (with a preference of fallen logs) was shown by Pulliainen (1980) by 
snowtracking in virgin boreal forests in northern Finland. Marten uses its sense of smell in searching for prey (Semenov-Tjan-Šanskij 1960, Spencer and Zielinski 1983) and have a long-term memory of places and caches (Sonerud 1985, 1989). Marten can approach a man imitating the squeal of a 'slaughtered bird nestling' (L. Tomiałojć, pers. comm.), which suggests that it locates prey by hearing, too.

Martens' intense preying on Clethrionomys voles seems to be common throughout its geographic range, which is very similar to that of Clethrionomys glareolus (Görner and Hackethal 1988). In 13 studies from the former Soviet Union reviewed by Grakov (1981), bank voles were found in an average of $44 \%(\mathrm{SD}=28)$ of all scats or stomachs that included rodent remains and were equally intensely consumed by martens in boreal and nemoral forests. Apodemus mice appeared in marten diet from about $55^{\circ} \mathrm{N}$ southward and were always less important prey than Clethrionomys (Grakov 1981). Mice are probably too agile to easily fall as prey to marten. This was confirmed by our data showing that yellow-necked mice were more intensively preyed upon by martens only in October - November, when mice were less active due to entering their daily torpor. At this time of the year, also weasels Mustela nivalis more easily captured mice than bank voles (Jędrzejewski et al. 1992 a). In regions, where neither Clethrionomys nor Microtus voles occur (as in Balearic Islands), Apodemus mice do not contribute to marten diet more than in places where mice coexist with microtine voles [only $11-17 \%$ of occurrence in scats (Moreno et al. 1988, Ruiz-Olmo and Nadal 1991)], whereas in northern region, where no mice are present, microtines may form up to $100 \%$ of marten food (Pulliainen 1980).

Similar dependence of the American marten Martes americana on Clethrionomys voles and its seldom feeding on Peromyscus was reported from North American forests (Douglass et al. 1983, Buskirk and MacDonald 1984, Slough et al. 1989). Interestingly, on Vancouver and Queen Charlottes Islands, where no microtines were present, Peromyscus was found in mere $4-15 \%$ of scats and martens compensated for the lack of microtines by preying more birds (Nagorsen et al. 1989, 1991).

Most probably Microtus voles are also easy and preferred prey to martens, whenever they can be found in the forests or along forest edges. Pine martens are rather reluctant to go far into open areas (Goszczyński 1985), so in the temperate zone, habitat selection of Microtus voles and that of marten diverge. In BNP, martens regularly hunted Microtus voles in open river valleys and meadows by the forest. Also, Lockie (1961) documented that in a clear forest in Scotland, where $M$. agrestis inhabited the forest, it was preyed upon more than the sympatric bank vole by marten. In northern boreal forests, where short-tailed voles inhabited woodlands, they were the most numerous rodents captured by martens (Parovščikov 1961; Arkhangelsk region).

At northern latitudes, where microtine rodents and shrews exhibit 3 to 5 -year cycles of numbers, their share in marten diet varies wildly from 4 to $100 \%$ of occurrence in scats (Pulliainen 1980). At a more southern latitude, rodent populations become weakly cyclic and then relatively stable with only seasonal variations 
(Hansson and Henttonen 1985), and the contribution of rodents to marten's diet is more stable (Goszczyński 1986). In our study area, where population dynamics of forest rodents was a combination of moderate years and regular outbreak-crash years, marten diet composition followed the changes of bank vole numbers. Bank vole abundance was a key factor determining the martens' winter predation not only on bank voles, but also on yellow-necked mice and small insectivores, as well as its scavenging on ungulate carcasses. In BNP, however, even during the crash year, rodents were found in about $40 \%$ of marten scats.

Alternative prey sources for marten in BNP were insectivores and ungulate carcasses in autumn-winter and birds and fruit in spring-summer. Compensatory scavenging on reindeer Rangifer tarandus carcasses was also observed by Pulliainen (1980) in northern boreal forests during vole decline. In our study area, carcasses were the last choice food to martens; during small declines of rodent availability, martens compensated for their scarcity by preying more on insectivores (in 1985/86 - 1988/89). It was the profound decline of rodents in 1991, that made pine marten scavenge intensely. In BNP, martens preferred to feed on remains of wolves' and lynx's kills rather than on ungulates that had died from undernutrition and disease. It may be an adaptive strategy against the transmission of disease and was facilitated by marten's ability to take the arboreal escape, when approached by a host-predator (wolf or lynx).

Pine marten is regarded one of the most serious bird-eaters among mammalian predators. In BNP, nearly $40 \%$ of biomass consumed by martens in June were birds, although the numbers of forest and field rodents were growing and producing cohorts of vulnerable young then. In spring and summer, martens preyed mainly on thrushes, nuthatches, flycatchers, wrens and jays. The census of birds done on 13 plots covering a total of 343 ha in BNP (Tomiałojć et al. 1984) showed that Turdus sp. (mainly T. philomelos) contributed on average $7.4 \%$ (SD $=1.1$, range $5.8-9.6$ ) to the community of breeding birds (or $11 \%$, if corrected acc. to Tomiałojć and Lontkowski 1989), in contrary to $30 \%$ of birds identified from marten diet. Ficedula sp. (albicollis, parva, and hypoleuca) contributed on average $7.4 \%$ to the community $(\mathrm{SD}=3.9$, range $1.5-10.6)$ and $13 \%$ to birds captured by martens. Nuthatch comprised on average $1.7 \%$ of the community $(\mathrm{SD}=1.1$, range $0-3.2$ ), jay $0.6 \%$ ( $\mathrm{SD}=0.2$, range $0.3-0.8$ ), and wren $2.7 \%(\mathrm{SD}=1.4$, range $0.3-4.5$ ). These 3 species contributed $9 \%$ each to birds identified from marten diet. On the other hand, chaffinch Fringilla coelebs, the most numerous bird in BNP, was not found in marten scats. No census of winter bird communities was done in BNP. However, assessment of densities of year-round residents (calculated from Tomiałojć et al. 1984), indicates that woodpeckers and nuthatches each comprised $20 \%$ of the winter bird community. Thus, in autumn-winter, martens killed the most available birds.

In only a very few studies, did the authors undertake the task of identifying bird remains in marten scats to species. In Switzerland, Turdus sp. comprised 44\% and Parus sp. 23\% of all identified birds (Marchesi and Mermod 1989). Four 
out of 13 small birds (31\%) recovered from marten stomachs near Arkhangelsk in winter were woodpeckers (Parovščikov 1961). Five of 11 small birds (45\%) found on marten trails by Goszczyński (1976) in western Poland were tits Paridae. Parus sp. $(41 \%)$ and wren (18\%) dominated the sample of 17 small birds recovered from marten scats in Scotland by Lockie (1961). Lockie (1961) also mentioned the negligible representation of chaffinch in marten diet. Although in each of these studies the sample of identified birds is inconclusively small, when taken together, they show a rather consistent trend of martens' selective preying on thrushes, tits, flycatchers, wrens and - particularly so in the cold season - woodpeckers. Tits, nuthatches, some flycatchers and woodpeckers are hole-nesters, thus are vulnerable to marten, which climbs a tree every kilometer of its trail (cf Table 7). In BNP, wrens built nests in the root plates of fallen trees and under fallen logs (Wesołowski 1983), locations frequently penetrated by martens (see Table 7).

In boreal forests of western Canada, birds captured by American martens Martes americana in winter on Queen Charlotte Islands were dominated by Picidae (31\% of identified birds) and Troglodytes troglodytes (26\%). On Vancouver Island, $39 \%$ of identified birds were wrens, $23 \%$ - flycatchers Muscicapidae, and $16 \%$ Picidae (Nagorsen et al. 1989, 1991).

In European boreal forests, large tetraonid birds dominate the avian prey of martens. At northern latitudes, willow grouse Lagopus lagopus, capercaillie Tetrao urogallus, black grouse Lyrurus tetrix, and hazel hen Tetrastes bonasia are preyed on by the marten year-round, but more intensely in winter than in summer. The results of 32 studies done in Europe between $68^{\circ} \mathrm{N}$ and $47^{\circ} \mathrm{N}$ show a significant trend of southward decrease in the occurrence of birds in marten scats and/or stomachs in autumn-winter (Fig. 8). This decrease concerns exclusively tetraonid birds (Fig. 8), which is explainable by the decreasing abundance of these boreal birds in the north-south gradient. The contribution of small birds to the autumn -winter diet of martens (assessed as the difference between the tetraonid line and all-birds line in Fig. 8) remains steadily low (about $8 \%$ occurrence) from the northernmost boreal forests to central European nemoral forests.

Tetraonid birds, as year-round residents, form a very important constituent of marten winter food in the north, when the snow depth makes it difficult to hunt microtine rodents. In years of rodent declines and low numbers, tetraonid birds are crucial winter alternative food to martens (Pulliainen 1980) and then, martens' predation on tetraonids may be substantial (Marcström et al. 1988).

In five studies done in the northern boreal forests in both the cold and warm season, the percent occurrence of birds in marten stomachs was from 1 to $25 \%$ (on average $12 \%$ ) lower in spring-summer than in autumn-winter (Laplandskii game reserve - Nasimovič 1948; Upper Pechora river - Jazan 1962, Jurgenson 1951; Arkhangelsk and Kirov regions - Grakov 1981; Karelia - Danilov and Ivanter 1967). In deciduous forests, where martens prey only on small birds, the avian prey is no longer a reliable winter food, but it becomes an important spring-summer resource (Dackevič 1979, Marchesi and Mermod 1989, and this study). 


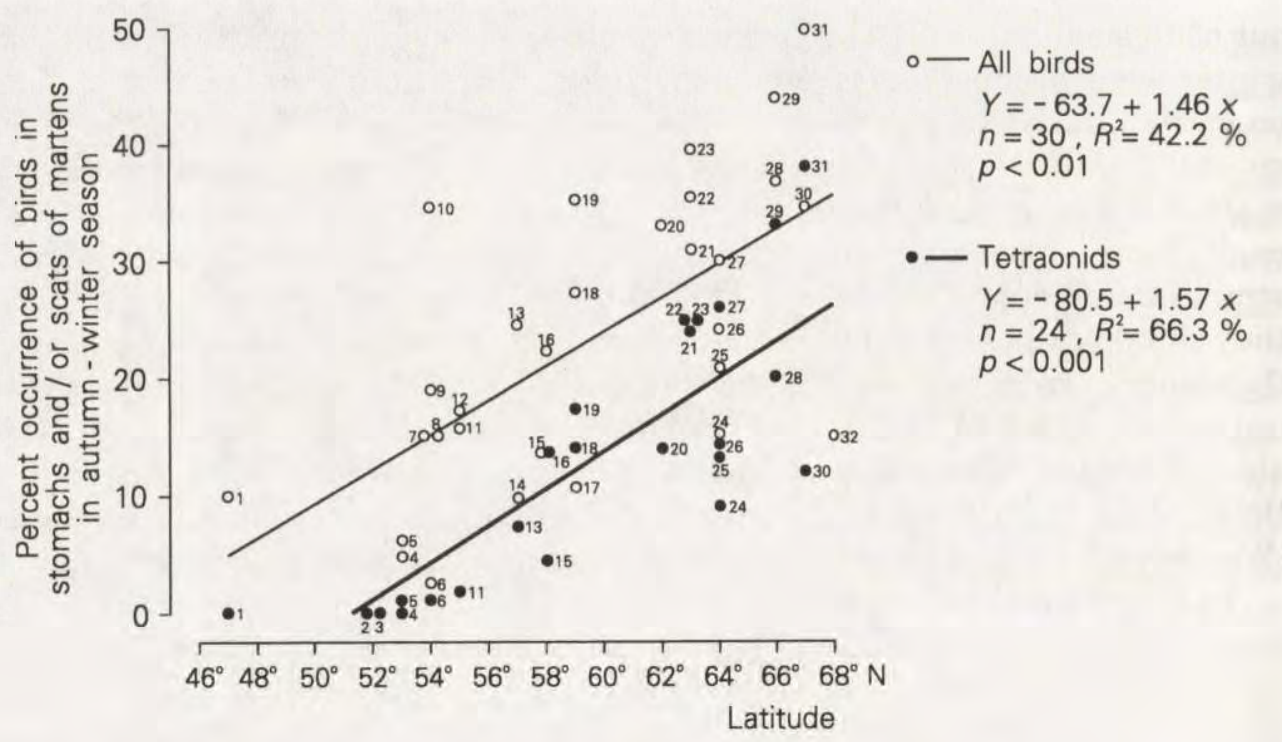

Fig. 8. Geographic variation in percent occurrence of all birds and tetraonid birds in the stomachs and/or scats of pine marten in the autumn-winter season in Europe.

Sources and regions: (1) Swiss Jura Mts, Marchesi and Mermod (1989); (2) W Poland, Goszczyński (1976); (3) C Poland, Goszczyński (1986); (4) Białowieża Forest, E Poland (this paper); (5) Białowieża Forest, W Belarus, Dackevič (1979); (6) Belarus, Seržanin (1973); (7) Southern Urals, Russia, Aspisov (1973); (8) Smolensk region, Russia, Grakov (1981); (9) Ryazan region, Russia, Ivanov (1965); (10) Middle Volga river, Russia, Grakov (1981); (11) Lithuania, Maldziunaite (1959); (12) Volga-Kama rivers, Russia, Aspisov (1973); (13, 14) Central Urals, Russia, Bakeev (1966), Korjakov (1962); $(15,16)$ Perm region, Russia, Čaščin (1956), Grakov (1981); (17) South-central Sweden, Storch et al. (1990); $(18,19)$ Vologda region, Russia, Gribova (1958), Grakov (1981); (20) Karelia, St. Petersburg, Novgorod, Pskov regions, NW Russia, Morozov (1963); (21) Vychegda and Sysola rivers, N Russia, Poležaev (1982); (22) Karelia, N Russia, Danilov and Ivanter (1967); (23) Upper Pechora river, Russia, Jazan (1962); (24, 25) Northern Dvina river, Russia, Parovščikov (1961), Grakov (1981); (26) Arkhangelsk region, N Russia, Grakov (1981); (27) Central Timan Hills, N Russia, Poležaev (1982); (28) Pechora river, Russia, Grakov (1981); (29) Laplandskii Reserve, NW Russia, Nasimovič (1948); (30) Kirov region, Russia, Grakov (1981); (31) Northern Urals, Russia, Poležaev (1982); (32) N Finland, Pulliainen (1980).

However, in transformed habitats of small woods and field mosaic, where partridges Perdix perdix and introduced pheasants Phasianus colchicus are abundant year-round residents, they are often preyed upon by martens and become important winter alternative food consumed more intensely, when rodents are less available (Goszczyński 1986).

The occurrence of vegetal food in pine marten diet does not show any geographical trend throughout the $20^{\circ}$ latitude in Europe. Berries, mushrooms, and rowan fruit were reported from both the northern (Grakov 1981) and southern latitudes (Goszczyński 1976, 1986, Marchesi and Mermod 1989, this study). In some southernmost localities of pine marten range, e.g. Balearic Islands, the fruit 
(mainly figs) may comprise nearly $50 \%$ of all food biomass of this carnivore (Moreno et al. 1988, Ruiz-Olmo and Nadal 1991).

Consumption of honey and larvae of bees and wasps was recorded in boreal forests (Karelia-Danilov and Ivanter 1967; Pskov and Petesburg regions Morozov 1976), Central European nemoral forests (this study), montane forests of Central Europe (Marchesi and Mermod 1989), and central and southern parts of Russia (Aspisov 1973, Grakov 1981).

In conclusion, the results of our study and the review of extensive data from other European woodlands show that the foraging strategy of pine marten is based on two adaptations: (1) specialisation on Clethrionomys voles (which are a single most important prey species in marten diet in boreal and nemoral forests in Europe) and other microtine rodents, and (2) capability to survive the regular (seasonal and multi-annual) great fluctuations of numbers of this main prey by preying on alternative resources. The choice of alternative resources (birds, vegetal matter, insectivores, carcasses) is determined by both their local abundance and marten's hunting behaviour.

Acknowledgements: We thank the technician staff of MRI (E. Bujko, M. Szlachciuk, J. Siemieniuk, M. Świć, K. Zub), students of Forestry College in Białowieża (supervised by A. Szymura, M.Sc.), students of Farnborough College of Technology (England) and Earthwatch Research Corps for their field work. We appreciated the volunteer work of many students and amateurs. Laboratory and computer work was done by L. Szymura, N. Wojcieszuk, S. Bogdańska, L. Siemieniuk, and K. Zub. Drs A. L. Ruprecht and M. Keller consulted the identification of vertebrate remains, and Dr T. Pawlikowski identified Hymenoptera insects. Mr. R. Gehman kindly revised the English usage. We are grateful to Drs J. Goszczyński, Z. Pucek, M. Sandell, and L. Tomiałojć who kindly commented on the earlier draft. The study was supported by grants CPBP 04.10, Earthwatch, and KBN 444169102.

\section{References}

Aspisov D. I. 1973. [Volga-Kama rivers country]. [In: Sable, martens, and yellow-throated marten: Distribution of resources, ecology, harvest, and protection. A. A. Nasimovič, ed]. Izd. Nauka, Moskva: 161 - 172. [In Russian]

Bakeev Ju. N. 1966. [On food of pine marten in the Middle Urals]. Učen. zap. Ural'skogo universiteta, Ser. Biol. 43 (3): 58 - 65. [In Russian]

Buskirk S. W. and MacDonald S. O. 1984. Seasonal food habits of marten in south-central Alaska. Can. J. Zool. 62: 944 - 950.

Caščin S. P. 1956. [Pine marten of Kama Predural'e and its economic importance]. Ph. D. thesis, University of Perm. [In Russian]

Dackevič V. A. 1979. [Food of pine marten in Beloveža Forest]. Zapovedniki Belorussi 3: 67 - 70. [In Russian]

Danilov P. I. and Ivanter E. V. 1967. [Pine marten in Karelia]. Učen. zap. Petrozavodsk. Univ. 15: 179 - 197. [In Russian]

Debrot S. 1982. Atlas des poils de mammiferes d'Europe. Universite de Neuchâtel: 1 - 208.

Douglass R. J., Fisher L. G. and Mair M. 1983. Habitat selection and food habits of marten, Martes americana, in the Northwest Territories. Can. Field-Nat. 97: $71-74$.

Dziurdzik B. 1973. Key to the identification of hairs of mammals from Poland. Acta zool. crac. 18: 73 - 91. [In Polish with English summary] 
Fairley J. S., Ward D. P. and Smal C. M. 1987. Correction factors and mink faeces. Ir. Nat. J. 22 $334-336$.

Faliński J. B. 1986. Vegetation dynamics in temperate lowland primeval forests. Dr W. Junk Publishers, Dordrecht, Geobotany 8: 1 - 537.

Goszczyński J. 1974. Studies on the food of foxes. Acta theriol. 19: 1- 18 .

Goszczyński J. 1976. Composition of the food of martens. Acta theriol. 21: 527 - 534.

Goszczyński J. 1977. Connections between predatory birds and mammals and their prey. Acta theriol. 22: $399-430$.

Goszczyński J, 1985. The effect of structural differentiation of ecological landscape on the predator-prey interactions. Publications of Warsaw Agricultural Univ. SGGW-AR. Treatises and Monographs, Warsaw: $1-80$. [In Polish with English summary]

Goszczyński J. 1986. Diet of foxes and martens in Central Poland. Acta theriol. 31: $491-506$.

Görner M. and Hackethal H. 1988. Säugetiere Europas. Neumann Verlag, Leipzig: 1 - 371.

Grakov N. N. 1981. [Pine marten]. Izd. Nauka, Moskva: 1 - 110. [In Russian]

Gribova Z. A. 1958. [Food of pine marten in Vologda region]. Trudy Vsesojuznogo Nauč.-Isled. Inst. životnogo syr'ya i pušniny 17: 70-79. [In Russian]

Hansson L. 1987. An interpretation of rodent dynamics as due to trophic interactions. Oikos 50: $308-318$.

Hansson L. and Henttonen H. 1985. Gradients in density variations of small rodents: the importance of latitude and snow cover. Oecologia 67: $394-402$.

Ivanov F. V. 1965. [Numbers of pine marten in Ryazan region]. [In: Ohotniče - promyslovye zveri]. Moskva. [In Russian]

Jacobs J. 1974. Quantitative measurements of food selection; a modification of the forage ratio and Ivlev's Electivity index. Oecologia 14: $413-417$.

Jazan Ju. P. 1962. [Is the marten responsible for the decrease of red squirrel numbers?] Zool. Ž. 41: 633 - 635. [In Russian]

Jędrzejewski W. and Jędrzejewska B. 1992. Foraging and diet of the red fox Vulpes vulpes in relation to variable food resources in Białowieża National Park, Poland. Ecography 15: $213-221$.

Jędrzejewski W. and Jędrzejewska B. 1993. Predation on rodents in Białowieża Primeval Forest, Poland. Ecography 16: $47-64$.

Jędrzejewski W., Jędrzejewska B. and McNeish E. 1992a. Hunting success of the weasel Mustela nivalis and escape tactics of forest rodents in Białowieża National Park, Poland. Acta theriol, 37: $319-328$.

Jędrzejewski W., Jędrzejewska B., Okarma H. and Ruprecht A. L. 1992b. Wolf predation and snow cover as mortality factors in the ungulate community of the Białowieża National Park, Poland Oecologia 90: $27-36$.

Jurgenson P. B. 1951. [Ecological-geographical aspects of feeding by pine marten and the geographic variability of ecological-morphological adaptations of its chewing apparatus]. Zool. Ž. 30: 172 - 185. [In Russian]

Jurgenson P. B. 1954. [On the impact of pine marten on the numbers of red squirrels in the northern boreal forests]. Zool. Z. 33: 166 - 173. [In Russian]

Korjakov B. F. 1962. [The mole in food of marten], Sbornik nauč,-tehnič. informacii (VNIIZhP), 4 (7): 29 - 30. [In Russian]

Langley P. J. 1977. The decline of rarer carnivores in Great Britain during the XIX-th century. Mammal Rev. 7: $95-116$.

Levins R. 1968. Evolution in changing environment. Princeton Univ. Press, Princeton.

Lockie J. D. 1959. The estimation of the food of foxes. J. Wildl. Manage. 23: 224-227.

Lockie J. D. 1961. The food of the pine marten Martes martes in West Ross-Shire, Scotland. Proc. zool. Soc. Lond. 136: 187 - 195 .

Maldziunaite S. 1959. [Biology of pine marten in Lithuania]. Lietuvos TSR Mokslu Akademijos Darbai, Ser. B, 1(17): 189 - 201. [In Lithuanian with Russian summary] 
Marchesi P. and Mermod C. 1989. Regime alimentaire de la martre (Martes martes L.) dans le Jura suisse (Mammalia: Mustelidae). Revue Suisse Zool. 96: 127 - 146.

Marcström V., Kenward R. E. and Engren E. 1988. The impact of predation on boreal tetraonids during vole cycles: an experimental study. J. Anim. Ecol. 57: 859-872.

März R. 1987. Gewoll- und Rupfungskunde. Akademie-Verlag, Berlin: 1 - 398.

Moreno S., Rodriguez A. and Delibes M. 1988. Summer foods of the pine marten (Martes martes) in Majorca and Minorca, Balearic Islands. Mammalia 52: $289-291$.

Morozov V. F. 1963. [Material on food of pine marten in the North-west RSFSR], [In: Promyslovaja fauna i ohotniče hozaistvo Severo-Zapada RSFSR. Sbornik Trudov]. Leningrad: $124-132$. [In Russian]

Morozov V. F. 1976. Feeding habits of Martes martes (Carnivora, Mustelidae) in different regions of the North-west of the USSR. Zool. Ż. 55: 1886 - 1892. [In Russian with English summary]

Nagorsen D. W., Morrison K. F. and Forsberg J. E. 1989. Winter diet of Vancouver Island marten (Martes americana). Can. J. Zool. 67: 1394-1400.

Nagorsen D. W., Campbell R. W. and Giannico G. R. 1991. Winter food habits of marten, Martes americana, on the Queen Charlotte Islands. Can. Field-Nat. 105: 55 - 59.

Nasimovič A. A. 1948. [Ecology of the pine marten]. Trudy Laplandskogo zapovednika 3: 81 - 106. [In Russian]

Olszewski J. L. 1968. Role of trees in the movements of rodents in forests. Oikos 19: $99-104$

Olszewski J. L. 1986. The role of forest ecosystems in modifying local climate of the Białowieża Primeval Forest, as revealed by air temperature characteristics. Wydawnictwo PAN (Prace habilitacyjne), Ossolineum, Wrocław: 1-222. [In Polish with English summary]

Parovščikov V. Ja. 1961. On feeding habits of Martes martes borealis B. Kuztnetz. near Archangelsk. Zool. Ž. 40: 1112 - 1115. [In Russian with English summary]

Poležaev N. M. 1982. [Trophic relationships of the pine marten in the North-east part of European boreal forests]. Trudy Komi filiala Akademii Nauk SSSR 51: 46 - 54. [In Russian]

Pucek Z. (ed) 1984. [Key to identification of Polish mammals]. PWN - Polish Scientific Publishers, Warszawa: 1 - 387. [In Polish]

Pucek Z., Jędrzejewski W., Jędrzejewska B. and Pucek M. 1993. Rodent population dynamics in a primeval deciduous forest (Białowieża National Park) in relation to weather, seed crop, and predation. Acta theriol. 38: $199-232$.

Pulliainen E. 1980. Food and feeding habits of the pine marten in Finnish forest Lapland in winter [In: Worldwide Furbearer Conference Proceedings. J. J. Chapman and D. Pursley, eds]. R. R. Donelley, Falls Church, VA: $580-598$.

Ruiz-Olmo J, and Nadal J. 1991. Regime alimentaire de la martre (Martes martes L., 1758) en hiver et taille des portees a Menorca, Iles Baleares. Mammalia 55; $639-642$.

Semenov-Tjan-Sanskij O. 1960. [Ecology of tetraonid birds]. Trudy Laplandskogo Gos. Zapovednika 5: 1 - 318. [In Russian]

Seržanin Ju. I. 1973. [Belarus]. [In: Sable, martens, and yellow-throated marten: Distribution of resources, ecology, harvest, and protection. A. A. Nasimovič, ed]. Izd. Nauka, Moskva: 155 - 158. [In Russian]

Slough B. G., Archibald W. R., Beare S. S. and Jessup R. H. 1989. Food habits of martens, Martes americana, in the south-central Yukon Territory. Can. Field-Nat. 103: 18 - 22.

Sonerud G. A. 1985. Nest hole shift in Tengmalm's owl Aegolius funereus as defence against nest predation involving long-term memory in the predator. J. Anim. Ecol. 54: 179 - 192.

Sonerud G. A. 1989. Reduced predation by pine martens on nests of Tengmalm's owl in relocated boxes. Anim. Behav. 37: $332-343$.

Spencer W. D. and Zielinski W. J. 1983. Predatory behaviour of pine martens. J. Mammal. 64: $715-717$.

Storch I., Lindström E. and de Jounge J. 1990. Diet and habitat selection of the pine marten in relation to competition with the red fox. Acta theriol, 35: $311-320$. 
Tomiałojć L. and Lontkowski J. 1989. A technique for censusing territorial song thrushes Turdus philomelos. Ann. zool. Fenn. 26: 235 - 243.

Tomiałojć L., Wesołowski T. and Walankiewicz W. 1984. Breeding bird community of a prinevæal temperate forest (Białowieża National Park, Poland). Acta orn. 20: $241-310$.

Wesołowski T. 1983. The breeding ecology and behaviour of wrens Troglodytes troglodytes under primeval and secondary conditions. Ibis 125: $499-515$.

Received 16 August 1993, accepted 3 November 1993. 